DOI: http://dx.doi.org/10.33846/hn40606

http://heanoti.com/index.php/hn

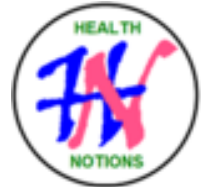

RESEARCH ARTICLE

URL of this article: http://heanoti.com/index.php/hn/article/view/hn40606

\title{
Analysis of the Quality of Health Center Services Based on Public Service Regulation by the Government
}

\author{
Ambo Dalle ${ }^{1(\mathrm{CA})}$, Sri Purwantono², Bahtiar $^{3}$ \\ ${ }^{1(\mathrm{CA})}$ Department of Nursing, Poltekkes Kemenkes Makassar, Indonesia; medikes@ gmail.com (Corresponding \\ Author) \\ ${ }^{2}$ Health Office of Ngawi Regency, Jawa Timur, Indonesia; purwanton@ gmail.com \\ ${ }^{3}$ Department of Nursing, Poltekkes Kemenkes Makassar, Indonesia; bahtiar.poltekkes@com
}

\begin{abstract}
Health centers are expected to provide quality health services that meet the needs of the customers. Health centers need to improve services in order to be able to compete, develop, and grow. This study describe the satisfaction of the customers for services provided by Kendal Health Center, Ngawi, Indonesia. The population of this study were community who utilized health services at the Kendal Health Center in 2016. The sample were selected using quota sampling. Each unit of service given a quota of 20 respondents, while auxiliary health center were quota of 10 respondents, because the customer visit at a auxiliary health center were lower. The variable was the satisfaction with services provided by health center. Data were collected by filling out questionnaires, then analyzed descriptively using spiderweb diagram. In general, the results of the study indicate that the quality of health center services was in the good category, and all service units had succeeded in exceeding the predetermined targets.
\end{abstract}

Keywords: health center; service quality; public service

\section{INTRODUCTION}

In the Law of Republic of Indonesia No. 25 / 2009 concerning Services for Public, it has been explained that service for public is an activity in order to fulfill service needs in accordance with legislation for every citizen of goods, services and or services administrative services provided by public-service providers. In the part of explanation, it has been described that what is meant by public service providers is institutions and corporations that are authorized to provide public services using the state budget. ${ }^{(1)}$

Health centers that are at the forefront of health services are expected to be able to provide quality services that meet the needs of the public. Thus, health centers need to improve services in order to be able to compete, develop, and grow. Kendal Health Center, is one of the health service institution in Ngawi, Indonesia which is responsible for organizing health development. ${ }^{(2)}$

As an official institution that functions to provide services to the public, community health centers must continue to improve and maintain the quality of health services it provides. Referring to Nugroho (2011), there are many ways to measure the quality of service for the public, but in fact the most important indicator of service quality is the level of customer satisfaction. In connection with the foregoing, many experts in the field of management stated that in order to measure the quality of goods or services, the most important thing is to assess quality according to customer perceptions, namely in the form of customer satisfaction levels. ${ }^{(3)}$

Based on the explanation above, it is deemed necessary to conduct a community satisfaction survey (CSS) for the basic health services provided by the Kendal Health Center, in order to evaluate the extent to which the quality of health services according to the public perception as customers or service recipients. In Indonesia, the government has issued regulations on the procedures for implementing CSS through the Minister of Administrative Reform and Bureaucratic Reform Regulation No. 16/2014 on "Guidelines for Community Satisfaction Surveys in Public Service Delivery". In addition, CSS is also intended to assess the current condition of public services, which can then be used as a reference for developing and improving service quality on an ongoing basis, so that in turn good governance of public service institutions can be realized. ${ }^{(4)}$ 
Based on the above background, in 2016, Puskesmas Kendal, Ngawi really felt that CSS is a very urgent need, so it must be implemented and followed up based on the results of the study obtained.

\section{METHODS}

This study was classified as a survey research, because this activity was only intended to describe the real conditions in the field, namely the satisfaction of the community as direct users of health services provided by the health center. The survey on community satisfaction with health center services was conducted at Kendal Health Center, Ngawi, Indonesia, in 2016. The population of this survey was all people who were users of basic health services at the Kendal Health Center in 2016. The sample was selected using a quota sampling technique. In this case, each service unit in the parent institution was given a quota of 20 customers as respondents, while specifically for auxiliary health center, each was given a quota of 10 respondents, because these units have fewer customers in their daily lives.

This study only describes one variable, namely the level of satisfaction with the basic health services provided by the health center, which is operationally defined as the total score of the results of filling out a questionnaire about the level of satisfaction with basic health services provided by the health center which includes 9 aspects, namely requirements, service time. , procedures, product specifications, fees / rates, behavior of officers, competence of officers, service announcements, as well as handling of complaints, suggestions and input.

Data regarding community satisfaction with basic health services was collected through filling out questionnaires by selected customers, but the filling process was assisted by previously trained enumerators.

The details of the research procedure are as follows:

1. The survey preparation meeting was attended by a team from the Ngawi District Health Office as the organizer of the activity and FORIKES as the survey operator.

2. Formulation of data collection instruments, namely a questionnaire developed based on the Regulation of the Minister of Administrative Reform and Bureaucratic Reform Number 16 of 2014 concerning "Guidelines for Community Satisfaction Survey on Public Service Delivery". The items in the questionnaire represent 9 predetermined service aspects, namely: requirements, service time, procedures, product specifications, fees / rates, officer behavior, officer competence, service announcements, as well as complaint handling, suggestions and input.

3. Enumerator training. This activity is carried out to ensure that the process and results of data collection are in accordance with the predetermined standards.

4. Implementation of data collection in the field, namely filling out questionnaires by customers who were assisted in filling it out by enumerators.

5. Data management which consists of: 1) editing, which aims to ensure that the data obtained is correct and complete, 2) coding, namely converting qualitative data into numbers, by referring to the coding guidelines listed in the questionnaire, 3) tabulating, namely entering the codes into the tables that have been prepared beforehand. This process is done using a computer program. All stages of data processing are carried out by enumerators, under the supervision of the supervisor.

6. Data analysis, which was carried out using descriptive statistical methods, either numerically in the form of an index or categorically as a description of the levels of quality.

The method of calculating the customer satisfaction index was as follows:

1. Calculating the mean-score of each element

2. Calculating the weighted mean-score of each element, using the following formula:

Weighted mean-score $=\sum$ weigh

$$
\sum \text { element }
$$

3. Calculating the customer satisfaction index

$\mathrm{CSI}=\sum$ (mean-score of each element X weighted mean-score) X 25

Then, the CSI was converted into a quality level category (Table 1).

Table 1 . The level of service quality of the community health center

\begin{tabular}{cccc}
\hline No & CSI & Quality Levels & Category \\
\hline 1 & 25 to 43.75 & D & Not good \\
2 & 43.76 to 62.50 & C & Poor \\
3 & 62.51 to 81.25 & B & Good \\
4 & 81.26 to 100.00 & A & Very good \\
\hline
\end{tabular}


The data were analyzed descriptively and presented in the form of spiderweb diagram.

\section{RESULTS}

The following shows the results of data analysis regarding the level of customer satisfaction or the quality of basic health services provided by the Kendal Health Center.

Table 2. The levels of customer satisfaction / quality of health service provided by kendal Health Center

\begin{tabular}{lccl}
\hline \multicolumn{1}{c}{ Unit } & Target & Achievement & Category \\
\hline Patient registration center & 62.51 & 78.13 & B (Good) \\
General clinic & 62.51 & 78.59 & B (Good) \\
Dental clinic & 62.51 & 78.13 & B (Good) \\
MCH clinic & 62.51 & 78.13 & B (Good) \\
Medicine room & 62.51 & 78.13 & B (Good) \\
Inpatient room & 62.51 & 78.13 & B (Good) \\
CHCA "Simo" & 62.51 & 78.13 & B (Good) \\
CHCA "Patalan" & 62.51 & 78.13 & B (Good) \\
CHCA "Karang Gupito" & 62.51 & 78.59 & B (Good) \\
\hline
\end{tabular}

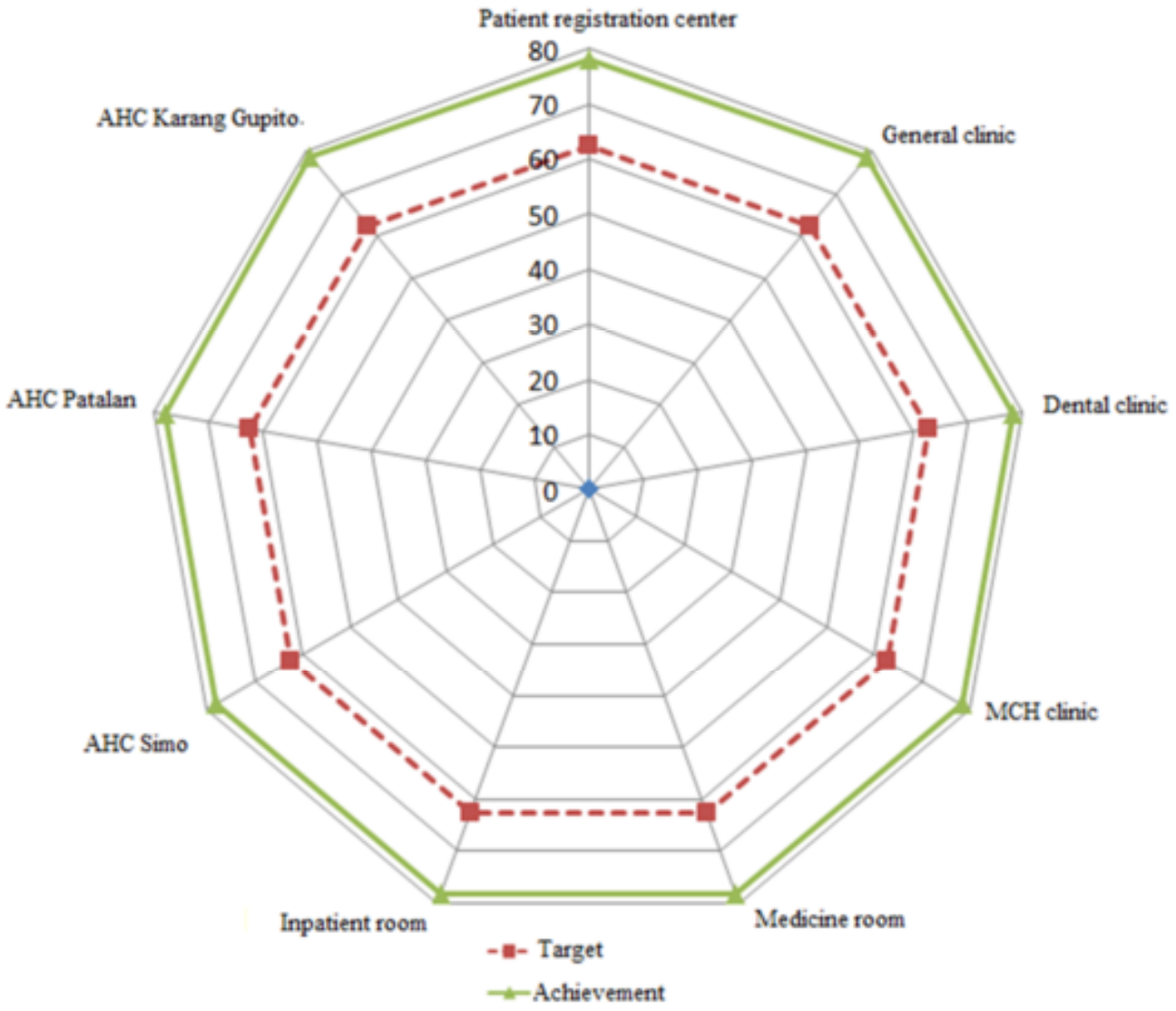

Figure 1. Customer satisfaction with health services at Kendal Health Center

Table 2 and Figure 1 show that basic health service quality in all Kendal Health Center service units, were in a good category and has exceeded the minimum quality target. The quality of each service unit was almost the same.

\section{DISCUSSION}

Through this survey activity, the measurement of the quality of basic health services at the Kendal health center has been successfully implemented in all health service units in the institution. The survey results showed that all health service units at the Kendal health center had exceeded the predetermined target or minimum standard of service quality, namely the customer satisfaction index reaching 62.51. This condition shows that 
the Kendal health center as a government institution that functions to provide health services to the community, has been able to provide basic health services properly as the government hopes. This shows the success of the Kendal health pust as an institution in charge of providing public services as stipulated in Law Number 25 of 2009 concerning Public Services, that public services are activities in order to meet service needs in accordance with statutory regulations for every citizen and resident of goods, services, and or administrative services provided by public service providers. ${ }^{(1)}$

The Kendal health center has succeeded in exceeding the minimum quality target that has been previously set, even though the achievement is still in the "good" category, or has not been able to reach the very good category. Thus, although the achievement of this "good" category has shown success, the journey to improve service quality is still a long way forward.

Based on the description above, efforts to improve towards the very good category must become an agenda for improving service quality in the coming fiscal year, because quality improvement must be sustainable. It should be noted that in this survey, the quality of basic health services provided by the Kendal health center was measured based on the perception of the community as customers. In this case, whatever the reality, if people are satisfied or very satisfied, it can be interpreted that these health services are of high quality, and vice versa, if people are not satisfied or very dissatisfied, it can be said that these health services are of low quality. . Therefore, the characteristics of the community as health center service users must always be followed by the development of health center managers. If the social status, economic status and education level of the people increase, this will affect the level of their expectations of the health services provided by the health center. The provision of the same service this year can be perceived differently by the community in the coming year. This is all the result of increasing education, knowledge and community experience. Basically, community satisfaction with health services is the result of community assessment of the services they receive, referring to the standards they have previously set themselves. ${ }^{(3)}$

Based on the description above, it can be seen that there is a consequence that in order to improve and maintain the quality of basic health services in health centers, all health services provided must refer to the most important standard, namely the expected quality, namely the level of service quality expected by the customer. In the information age like today, the flow of information is so swift that it will affect the level of quality of health services expected by customers. Customers not only expect quality but also expect quantity. For that, it is necessary to carry out other studies such as a survey of community needs for health center services. The results of this survey can be used as a reference in order to know the development of community expectations for health center services, so that everything that is needed by the community can be anticipated properly and immediately. Thus, the health center as the spearhead of basic health services in the community must always make efforts to improve the quality of health services as expected by the community as users.

There are important things that deserve attention related to the function of health centers that provide services in the form of services. Nugroho (2011) states that the quality of service is more difficult to measure compared to the provision of goods which are generally tangible or can be seen directly clearly, such as shape, color, texture, size and so on. In the utilization of health center services, only a few dimensions are visible, such as physical facilities and service personnel themselves. The rest are intangible dimensions that are relatively difficult to measure. The existing characteristics of the services make it difficult for researchers to determine what determines the quality of health services in the health center. Therefore, the measurement of the quality of health services by the health center must be carried out carefully, and refers to the methodology of measuring the quality of services appropriately. ${ }^{(3)}$

\section{CONCLUSION}

Based on the results, it could be concluded that the Kendal Health Center had achieved the quality of basic health services, which is in the good category.

\section{REFERENCES}

1. Republik Indonesia. Law of the Republic of Indonesia Number 25 of 2009 concerning Public Services (Undang-Undang Nomor 25 Tahun 2009 tentang Pelayanan Publik). Jakarta: Republik Indonesia; 2009.

2. Haksama S, et al. The Report of Community Satisfaction Index Survey on Community Health Center Services in Ngawi District in 2015 (Laporan Survei Indeks Kepuasan Masyarakat terhadap Pelayanan Pusat Kesehatan Masyarakat di Kabupaten Ngawi Tahun 2015). Surabaya: Pusat Studi Jaminan Sosial, Universitas Airlangga; 2015.

3. Nugroho HSW. Quality of Health Services According to Consumer Perception (Kualitas Layanan Kesehatan Menurut Persepsi Konsumen). Ponorogo: Forum Ilmiah Kesehatan (Forikes); 2011.

4. Kementerian PAN \& RB. Regulation of the Minister of Administrative Reform and Bureaucratic Reform, Number 16 of 2014 concerning "Guidelines for the Community Satisfaction Survey on the Implementation of Public Services". Jakarta: Kementerian Pendayagunaan Aparatur Negara dan Reformasi Birokrasi; 2014. 